\title{
PEMBIAYAAN SYARIAH DI SEKTOR PERTANIAN: SOLUSI PERMASALAHAN RIBA DALAM PERSPEKTIF SOSIAL DAN EKONOMI
}

\author{
Pradipta Puspita Larasati \\ Magister Sains Ekonomi Islam, Pasca Sarjana, Universitas Airlangga \\ Email: pradiptap196@gmail.com \\ Sayyidatul Fitriyah \\ Magister Sains Ekonomi Islam, Pasca Sarjana, Universitas Airlangga \\ Email: savitrisayyida@gmail.com \\ Tika Widiastuti \\ Magister Sains Ekonomi Islam, Pasca Sarjana, Universitas Airlangga \\ Email: tika.w@feb.unair.ac.id \\ Dian Berkah \\ Fakultas Agama Islam, Universitas Muhammadiyah Surabaya \\ Email: berkah.faiums@gmail.com
}

\begin{abstract}
ARTICLE HISTORY
Received:

30 November

2017

Accepted:

20 December

2017

Online available:

25 February 2018

Keywords:

Riba, Agricultural

Development,

Sharia Financing,

Islamic Financial

Institutions,

Islamic Banking.

As an agricultural country, the agricultural sector has a vital role in the development of the national economy. But it does not mean the agricultural sector work without an obstacle. In fact the sector is often faced with various problems, especially in the weakness of capital. The capital needs will increase along with various choices of commodities and cropping patterns, the development of cultivation technology, post- harvest handling and processing of increasingly rapid results. In the era of agricultural technology, intensive of capital mobilization for both agricultural equipment and production facilities. Farmers can not afford to finance their farms with their own funds so that the farmers decide to finance the majority of which come from conventional lending institutions or even loan sharks and "moneylenders" based on the interest system which contains the element of riba. This is what causes financing by using islamic financial institutions are still minimal. Over this condition, making an opportunity as well as a challenge for islamic financial institutions to be present in the community, especially farmers in the
\end{abstract}


agricultural sector, in order to minimize the action of riba in economic activity. As a solution, sharia financial institutions offer appropriate financing schemes in accordance with the needs of farners, but it can also be through the optimization of the function of islamic microfinance institutions (BMT) as an alternative in financing in the agricultural sector, the establishment of agricultural sharia banking and the application of rewards and punishment in financing. So the purpose of this study is expected by closer farmers with islamic financial institutions so that they can be completely free from the riba that can harm.

\section{Kata Kunci:}

Riba,

Pembangunan

Pertanian,

Pembiayaan

Syariah, Lembaga

Keuangan Syariah, Perbankan Islam.

\section{ABSTRAK}

Sebagai negara agraris, sektor pertanian memiliki peran vital didalam pembangunan perekonomian nasional. Namun bukan berarti sektor pertanian berjalan tanpa hambatan. Faktanya sektor tersebut sering dihadapkan pada berbagai permasalahan, terutama pada lemahnya permodalan. Kebutuhan modal akan semakin meningkat seiring dengan beragam pilihan jenis komoditas dan pola tanam, perkembangan teknologi budidaya, penanganan pasca panen dan pengolahan hasil yang semakin pesat. Pada era teknologi pertanian, pengerahan modal yang intensif baik untuk alat-alat pertanian maupun sarana produksi. Para petani tidak sanggup untuk membiayai usaha tani mereka dengan dana sendiri sehingga para petani memutuskan untuk melakukan pembiayaan yang mayoritas bersumber pada lembaga perkreditan konvensional atau bahkan rentenir dan para "lintah darat" yang berbasis pada sistem bunga, yang mengandung unsur riba. Hal inilah yang menyebabkan pembiayaan dengan menggunakan lembaga keuangan syariah masih minim. Atas kondisi inilah, menjadikan sebuah peluang sekaligus tantangan bagi lembaga keuangan syariah agar dapat hadir ditengah masyarakat khususnya para petani dalam sektor pertanian, agar meminimalisir tindakan riba dalam aktivitas perekonomian. Sebagai solusinya lembaga keuangan syariah menawarkan skema pembiayaan yang tepat sesuai dengan kebutuhan petani, selain itu bisa juga melalui optimalisasi fungsi dari lembaga keuangan mikro syariah (BMT) sebagai alternatif dalam pembiayaan di sektor pertanian, pembentukan bank pertanian syariah dan pengaplikasian reward dan punishment dalam pembiayaan. Sehingga tujuan dari penelitian ini diharapkan dengan mendekatkan petani dengan lembaga keuangan syariah sehinga mereka 
bisa benar-benar terbebas dari adanya riba yang dapat merugikan.

\section{PENDAHULUAN}

Secara tradisional, peranan pertanian dalam pembangunan hanya dipandang pasif. Sektor pertanian hanya dipandang sebagai sumber daya tenaga kerja dan bahan pangan yang murah demi perkembangan sektor industri yang lebih berdaya saing. Hal tersebut diperkuat dengan teori linear stages dari W.W Rostow (1960), yang menyatakan bahwa pembangunan ekonomi merupakan sebuah proses modernisasi dalam lima tahapan, artinya adanya pergerakan (transformasi) dari masyarakat yang berawal dari pertanian (tradisional) hingga kepada sektor industri (modern).

Sebagai contohnya beberapa negara seperti Jepang, China, dan Eropa yang mengawali revolusi industrinya diawali dari sektor pertanian. Jika melihat analisa dari sudut pandang permintaan, apabila sektor pertanian kuat, maka pendapatan riil perkapita akan naik, permintaan petani akan produk industri manufaktur akan naik, hal ini mengindikasikan terjadi perkembangan industri manufaktur. Sedangkan ketika melihat dari sudut pandang penawaran, permintaan produk pertanian sebagai bahan baku oleh industri manufaktur. Apabila terjadi kelebihan output sektor pertanian, maka dapat digunakan sebagai investasi sektor industri manufaktur seperti industri kecil di pedesaan.

Namun pada saat ini, para ekonom sudah mulai menyadari bahwa sektor pertanian dianggap vital dari kegiatan ekonomi suatu negara. Untuk menunjang pembangunan perekonomian nasional, dapat dilakukan dengan membangun sektor pertanian. Implementasinya tidak hanya ditunjukan melalui peningkatan status dan kesejahteraan petani semata, tetapi juga berperan untuk mengembangkan potensi sumberdaya manusia baik secara ekonomi, sosial, politik, budaya, lingkungan melalui perbaikan (improvement), pertumbuhan (growth) dan perubahan (change) (Sudaryanto, 2008).

Hal ini seperti yang terjadi di Indonesia yang menjadi sektor pertanian menjadi sektor utama yang dapat menyangga perekonomian dalam negeri (Nasution, 2016). Sebagai negara agraris, sektor pertanian dan pedesaan memiliki peran sangat strategis dalam pembangunan nasional. Namun, bukan berarti sektor pertanian dan pedesaan berjalan tanpa hambatan. Faktanya sektor tersebut sering dihadapkan pada berbagai permasalahan, terutama pada lemahnya permodalan. Sebagai unsur esensial dalam meningkatkan produksi dan 
taraf hidup masyarakat pedesaan, ketiadaan modal dapat membatasi ruang gerak sektor ini (Ashari, 2005).

Kebutuhan modal akan semakin meningkat seiring dengan beragam pilihan jenis komoditas dan pola tanam, perkembangan teknologi budidaya, penanganan pasca panen dan pengolahan hasil yang semakin pesat. Pada era teknologi pertanian, pengerahan modal yang intensif baik untuk alat-alat pertanian maupun sarana produksi tidak dapat dihindari. Masalah kembali muncul, karena sebagian besar petani tidak sanggup mendanai usaha tani yang padat modal dengan dana sendiri dan pembiayaan menjadi pilihan.

Mayoritas bentuk pembiyaan usaha sektor pertanian dan pedesaan bersumber dari lembaga perkreditan konvensional. Hal ini diperkuat oleh Ashari dan Saptana (2005) yang mengkaji pembiayaan pertanian di indonesia, hasilnya bahwa keberadaan program perkreditan merupakan salah satu unsur pelancar bagi keberhasilan dalam program pembangunan sektor pertanian, namun sampai saat ini perkreditan yang ada tersebut dirasa masih kurang memberikan manfaat bagi petani. Kemudian, menurut Kompas (2009) karena terbatasnya jaringan perbankan di desa, mayoritas sektor pertanian berada di desa, sedangkan perbankan berada di kota. Susahnya akses ke kota guna menjangkau perbankan yang ada di kota juga menimbulkan cost yang harus dikeluarkan oleh petani. Belum lagi akan ada banyak hal yang harus diurus oleh petani seperti misalnya urusan administrasi dan sebagainya, sehingga double cost bisa saja terjadi. Hal inilah yang menyebabkan petani lebih senang memilih alternatif pembiayaan yang lebih mudah dan murah untuk dijangkau seperti rentenir.

Peminjaman modal pada rentenir dan para "lintah darat" menggunakan sistem bunga, jatuhnya petani ke dalam hutang melalui sistem ijon dan rentenir mengakibatkan tidak tumbuhnya sektor pertanian Indonesia yang memiliki keunggulan komparatif. Pinjaman yang berdasarkan pada sistem bunga menimbulkan masalah baru seperti membengkaknya hutang petani serta kredit macet. Hal ini dikarenakan tidak ada alternatif pembiayaan yang lebih baik bagi petani.

Menurut Antonio (2001), sistem lembaga keuangan dengan sistem bunga memiliki aturan main yang berlaku, yaitu (1) bunga ditentukan di muka dengan asumsi bahwa kegiatan yang didanai harus untung; (2) persentase keuntungan ditetapkan berdasarkan modal yang dipinjamkan; (3) pembayaran bunga berlaku tetap tanpa mempertimbangkan alasan apapun; (4) walaupun keuntungan meningkat, jumlah pembayaran bunga tidak mengalami peningkatan. Penggunaan sistem bunga yang ditetapkan pada awal perjanjian menjadikan 
sistem ini sangat menghindari pendanaan kegiatan dengan risiko yang sangat tinggi, sehingga pendanaan kegiatan pertanian bukan merupakan sasaran utama optimalisasi perolehankeuntungan. Jika lembaga keuangan mendanai kegiatan pertanian, maka diberlakukan tingkat suku bunga yang sama dengan kegiatan komersial lainnya. Sehingga dalam jangka panjang, pendanaan bagi sektor ini semakin kecil jumlahnya.

Secara ekonomi, rentenir tentunya sangat merugikan masyarakat ditinjau dari sistem serta bunga yang dipatok kreditur terhadap debiturnya. Apabila ditinjau dari sisi Islam pun terdapat unsur riba yang dapat mengurangi kesejahteraan masyarakat terlebih masyarakat kalangan menengah ke bawah yang memiliki rasio perbandingan pendapatan dan pengeluaran yang jauh.

Dalam praktiknya, rentenir menarik bunga tinggi dan tata cara pengembalian yang ditetapkan oleh kreditur tanpa didasarkan oleh undangundang secara resmi. Praktik ini dipandang sebagai praktik yang memiliki polemik fiqih tersendiri di dalam khasanah Islam, terutama dalam masalah hukum tentang rate (bunga pinjaman). Definisi rate secara terminologis umum adalah suatu tambahan harga yang ditetapkan untuk pinjaman finansial, seringkali dinyatakan dalam bentuk persentase dan dihitung dari jumlah uang yang dipinjam (Wirdyaningsih, 2005: 21).

Mengingat kegiatan pertanian sangat dipengaruhi faktor alam yang merupakan faktor yang berada di luar kendali manusia dan output yang dihasilkan memiliki karakteristik khusus yaitu mudah rusak, beragam kuantitas dan kualitas, dan dengan harga yang sangat berfluktuasi, maka menurut Suroso (2004: 42) lembaga keuangan yang dibutuhkan yaitu lembaga keuangan yang memiliki 3 prinsip utama, yaitu: (1) menetapkan sistem bagi risiko dan bagi hasil secara adil, yaitu dengan memperhitungkan kemungkinan untung dan rugi; (2) menghindari penetapan besaran keuntungan di awal perjanjian; (3) menetapkan bagi hasil berdasarkan besarnya keuntungan yang diperoleh. Dan karakteristik ini sesuai dengan lembaga keuangan syariah.

Menurut penelitian yang dilakukan oleh Ashari (2009), pola pembiayaan syariah dapat dijadikan sebagai solusi alternatif karena perbankan syariah memiliki keunggulan diantaranya pada produk pembiayaan yang variatif serta tahan terhadap gejolak krisis moneter karena tidak berbasis bunga. Berikut adalah tabel persentase pembiayaan Bank Umum Syariah (BUS) dan Unit Usaha Syariah (UUS) : 
Tabel 1

Persentase Pembiayaan Bank Umum Syariah dan Unit Usaha Syariah, 2014-2016 (dalam Milyar Rupiah)

\begin{tabular}{|c|c|c|c|c|}
\hline No. & $\begin{array}{c}\text { Penerima Pembiayaan Lapangan } \\
\text { usaha }\end{array}$ & 2014 & 2015 & 2016 \\
\hline 1. & $\begin{array}{l}\text { Pertanian, Perburuan dan } \\
\text { Kehutanan }\end{array}$ & 4.96 & 7.95 & 8.5 \\
\hline 2. & Perikanan & 714 & 1.1 & 1.4 \\
\hline 3. & Pertambangan dan Penggalian & 4.5 & 6.1 & 6.6 \\
\hline 4. & Industri Pengolahan & 13.3 & 17.9 & 19.7 \\
\hline 5. & Listrik, gas dan air & 5.4 & 6.4 & 8.1 \\
\hline 6. & Konstruksi & 11.6 & 11.1 & 14.4 \\
\hline 7. & Perdagangan besar dan eceran & 22.7 & 25.9 & 30.3 \\
\hline 8. & $\begin{array}{l}\text { Penyediaan akomodasi dan } \\
\text { penyediaan makan dan minum }\end{array}$ & 1.5 & 2.1 & 3 \\
\hline 9. & $\begin{array}{l}\text { Transportasi, pergudangan dan } \\
\text { komunikasi }\end{array}$ & 12.1 & 11.0 & 10.9 \\
\hline 10. & Perantara keuangan & 16.8 & 19.1 & 18.9 \\
\hline 11. & $\begin{array}{l}\text { Real Estate, usaha persewaan dan } \\
\text { jasa perusahaan }\end{array}$ & 7.6 & 9.3 & 12.7 \\
\hline 12. & $\begin{array}{l}\text { Administrasi pemerintahan, } \\
\text { pertahanan dan jaminan sosial } \\
\text { wajib }\end{array}$ & 85 & 266 & 9 \\
\hline 13. & Jasa pendidikan & 2.3 & 3.1 & 3.7 \\
\hline 14. & Jasa kesehatan dan kegiatan sosial & 1.7 & 2.5 & 3 \\
\hline 15. & $\begin{array}{l}\text { Jasa kemasyarakatan, sosial budaya, } \\
\text { hiburan dan lainnya }\end{array}$ & 6.7 & 4.6 & 4.6 \\
\hline
\end{tabular}

Sumber: Data Statistik Perbankan Syariah , 2014-2016

Berdasarkan tabel diatas, ternyata proporsi pembiayaan dari BUS dan UUS terhadap sektor pertanian ternyata masih rendah, mencermati peranan sektor pertanian yang sangat strategis dan kondisi mikro yang spesifik, sektor ini memerlukan lembaga penunjang yang spesifik pula. Menurut Arifin (2004:17) pemulihan perekonomian nasional dapat dilakukan dengan baik bila menetapkan sektor pertanian sebagai sektor pemicu (the leading sector) dengan disertai perbaikan operasionalisasi lembaga keuangan sebagai salah satu lembaga penunjang yang sangat penting.

Berangkat dari latar belakang tersebut penulis tertarik untuk mencari penyebab rendahnya pembiayaan BUS maupun UUS pada sektor pertanian serta solusi alternatif pembiayaan yang sesuai dengan petani agar petani tidak terjebak dalam praktek riba yang merugikan.

\section{LANDASAN TEORI}


Pada bab ini membahas beberapa hasil temuan penelitian sebelumnya.

1 Dampak Sosial dan Ekonomi dari adanya Riba

1.1 Dampak Ekonomi: Diantara dampak ekonomi riba adalah dampak inflatoir yang diakibatkan oleh bunga sebagai biaya uang. Hal tersebut disebabkan karena salah satu elemen dari penentuan harga adalah suku bunga. Semakin tinggi suku bunga, semakin tinggi juga harga yang akan ditetapkan pada suatu barang (Antonio, 2001:67).

a. Inflasi

Komponen bunga dimasukkan dalam komponen biaya. Perusahaan yang memperoleh pinjaman dari bank, harus membayar sejumlah bunga. Biaya bunga dibebankan pada komponen harga pokok. Harga pokok akan berpengaruh pada harga jual barang, sehingga harga jual barang meningkat karena didalamnya ada unsur bunga yang dibebankan pada pembeli. Secara nasional pembebanan bunga kepada pembeli akan menaikkan harga, sehingga akan menyebabkan inflasi (Ismail, 2010:21).

b. Ketergantungan Ekonomi

Dampak lainnya bahwa hutang, dengan rendahnya tingkat penerimaan pinjaman dan tingginya biaya bunga, akan menjadikan peminjam tidak pernah keluar dari ketergantungan, terlebih lagi bila bunga atas tersebut dibungakan. Contoh paling nyata adalah utang negara-negara berkembang kepada negaranegara maju. Meskipun disebut pinjaman lunak, artinya dengan suku bunga rendah, pada akhirnya negara-negara pengutang harus berutang lagi untuk membayar bunga dan pokoknya. Akibatnya, terjadilah hutang yang terusmenerus. Ini yang menjelaskan terjadinya kemiskinan struktural yang menimpa lebih dari separuh masyarakat dunia.

\subsection{Dampak Sosial}

a. Ketidakadilan

Bunga akan diterima oleh pihak pemberi pinjaman, sedangkan pihak peminjam akan membayar bunga. Pemberi pinjaman akan menerima bunga sebagai pendapatan. Sebaliknya, peminjam akan membayar bunga sebagai pengeluaran. Pemberi pinjaman akan selalu diuntungkan karena mendapat bunga dari peminjam, sebaliknya peminjam akan selalu rugi karena dibebani biaya atas utang yang dipinjam (Ismail, 2010:21).

b. Ketidakpastian 
Peminjam akan selalu membayar bunga sesuai dengan persentase yang telah diperjanjikan. Pemberi pinjaman tidak mempertimbangkan apakah dana yang dipinjamkan kepada peminjam telah digunakan untuk usaha dan menghasilkan keuntungan. Pemberi pinjaman selalu mendapatkan keuntungan meskipun peminjam menderita kerugian. Di dalam perjanjian, dipastikan bahwa peminjam akan mendapat keuntungan atas uang pinjamannya, padahal usaha yang dilakukan oleh peminjam masih mengandung unsur ketidakpastian apakah akan mendapat keuntungan atau menderita kerugian. Bila peminjam mendapat keuntungan, maka sepantasnya bila peminjam membagi hasil atas keuntungan. Sebaliknya, bila peminjam menderita kerugian, tentunya tidak perlu membayar tambahan kepada pemberi pinjaman.

Riba merupakan pendapatan yang didapat secara adil. Para pengambil riba menggunakan uangnya untuk memerintahkan orang lain agar berusaha mengembalikannya, misalnya, dua puluh lima persen lebih tinggi dari jumlah yang dipinjamkannya. Persoalannya, siapa yang bisa menjamin bahwa usaha yang dijalankan oleh orang itu nantinya mendapatkan keuntungan lebih dari dua puluh lima persen? Semua orang. Apalagi yang beragama, tahu bahwa siapa pun tidak bisa memastikan apa yang terjadi besok atau lusa. Siapun tahu bahwa usaha memiliki dua kemungkinan: berhasil atau gagal. Dengan menetapkan riba, orang sudah memastikan bahwa usaha yang dikelola pasti untung (Antonio, 2001:67).

Asaad (2010), melakukan kajian mengenai pemanfaatan lembaga keuangan syariah dalam sektor pertanian. Hasil penelitiannya menekankan bahwa bank syariah mempunyai peranan yang sangat penting untuk mendukung pembangunan nasional, khususnya pembangunan pertanian. Sektor pertanian merupakan sumber mata pencaharian sebahagian besar penduduk Indonesia. Sudah selayaknya bank syariah dapat berperan lebih dalam meningkatkan kesejahteraan masyarakat, terutama untuk mengentaskan kemiskinan. Ajaran Islam sangat menekankan urgensi keberpihakan kepada masyarakat kecil. Peranan bank syariah untuk pembiayaan usaha pertanian dapat ditingkatkan dengan menggunakan strategi: (1) Mengembangkan kantor bank syariah pada daerah pertanian. (2) Memberikan pembiayaan syariah yang lebih besar kepada usaha pertanian. (3) Melakukan pemasaran produk pembiayaan bank syariah kepada usaha pertanian. (4) Memberikan pembiayaan bank syariah yang sesuai dengan usaha pertanian secara penuh, agar potensi kegagalan panen dapat diminimalisir.

Masrifah (2010) melakukan penelitian menganai manfaat Baitul Mal Wat Tamwil (BMT) sebagai alternatif pembiayaan di sektor pertanian. Menurutnya 
sektor pertanian memiliki peran penting dalam pembangunan ekonomi di Indonesia. Namun sektor pertanian memiliki banyak permasalahan yang harus dihadapi, salah satunya kesulitan mengakses pembiayaan usaha yang diberikan oleh lembaga keuangan dan perbankan syariah. Hasil penelitiannya menunjukkan BMT sebagai alternatif strategis untuk mempromosikan usaha mikro kecil di sektor pertanian adalah dengan menyediakan skema pembiayaan alternatif berdasarkan sub-kegiatan, membentuk Program Keterkaitan antara BUS-BPRS-LKA-Pemerintahan, mengatur skema insentif, dan pembentukan Bank Pertanian Nasional, yang akan sepenuhnya fokus pada proyek-proyek di bidang pertanian.

\section{METODE PENELITIAN}

Penelitian ini merupakan kajian literatur yang bersumber pada berbagai kajian studi yang telah dilakukan sebelumnya, serta didukung dengan hasil kajian yang dipublikasikan oleh berbagai lembaga berupa jurnal dan kajian ilmiah lainnya.

\section{HASIL DAN PEMBAHASAN}

Pada bab ini membahas secara mendalam mengenai konsep pelarangan riba dalam perspektif sosial dan ekonomi yang diaplikasikan pada sektor pertanian.

\section{Penyebab Rendahnya Pembiayaan Syariah di Sektor Pertanian}

Secara umum, penyebab rendahnya pembiayaan syariah disektor pertanian adalah risiko pada pembiayaan pertanian cukup besar, yaitu risiko musiman seperti cuaca buruk ataupun hama penyakit, antara resiko yang besar dengan cost serta keuntungan tidak sebanding, barang yang dipesan saat jatuh tempo tidak ada dan kualitasnya tidak bagus, harus memiliki tempat penyimpanan atau gudang, harga tidak bisa ditentukan setelah panen, waktu yang harus menunggu dan hasil panen tidak sesuai dengan harapan (Affandi, 2014).

Asaad (2012) menjabarkan beberapa permasalahan yang menyebabkan masih kurangnya peranan bank syariah dalam pembiayaan usaha pertanian antara lain:

1. Pembiayaan yang diberikan bank syariah kepada usaha pertanian masih lebih sedikit dibandingkan dengan usaha lain, beberapa faktor penyebabnya antara lain: Karakter dari petani yang memiliki pola hidup yang cenderung konsumtif, sehingga mudah tertipu dengan pihak-pihak seperti tengkulak yang akhirnya mengakibatkan petani hidup dalam kemiskinan. 
2. Petani mengelola usaha taninya dengan cara yang tidak profesional dikarenakan kurangnya kemampuan petani untuk menata usahanya dengan baik, juga kurangnya perhatian pemerintah terhadap usaha pertanian yang merupakan dasar dari segala jenis usaha lainnya termasuk dalam hal kepastian harga.

3. Petani sulit untuk mendapatkan legalitas usahanya sehingga tidak mendapat kepercayaan dari perbankan syariah untuk memberikan pembiayaan syariah.

4. Kurangnya pengetahuan petani terhadap perbankan syariah dikarenakan lokasi perbankan syariah yang cenderung jauh dari usaha pertanian, sedikitnya pengenalan yang dilaksanakan perbankan syariah terhadap usaha pertanian dan sifat petani yang cenderung sulit menerima perubahan.

Pemikiran tersebut diperkuat oleh Mançka (2010) yang menemukan beberapa akar permasalahan mengenai pembiayaan pada sektor pertanian dan agroindustri sehingga diperlukan tindakan solutif yang harus diambil. Hasil penelitian menjelaskan permasalah yang dihadapi sektor tersebut adalah sektor pertanian menghadapi berbagai risiko tinggi (cuaca, hama, kandungan gizi dalam produksi), kebanyakan petani tidak memiliki jaminan dalam pembiayaan karena skala usaha pertanian adalah mikro kecil, ketidaksesuaian kondisi dan batas waktu pembayaran pembiayaan sesuai dengan siklus bisnis (khususnya untuk pertanian), bunga yang dikenakan terlalu tinggi serta jauhnya jarak bank dari daerah pedesaan.

Pada dasarnya sudah ada akad pembiayaan dalam sektor pertanian yaitu akad salam, yang akan menguntungkan baik dari lembaga keuangan syariah maupun petaninya apabila kualitas dan kuantitas barang sesuai dengan kesepakatan awal. Namun bukan berarti akad salam tidak menghadapi berbagai persoalan, antara lain: (1) apabila petani mengalami gagal panen, maka kuantitas dan kualitas barang tidak akan sesuai dengan apa yang telah disepakati sejak awal; (2) Permasalahan operasionalisasi yang mungkin dihadapi dalam pembiayaan salam adalah sulitnya memberi pemahaman calon nasabah tentang pembiayaan salam, serta mengawasi petani agar supaya tetap menjaga kualitas dan kuantitas hasil panennya (Roziq, 2014); (3) kurangnya sosialisasi akad syariah, banyak faktor yang dapat menyebabkan tidak diterapkannya akad salam di dunia perbankan syariah, diantaranya kurangnya pemahaman para praktisi perbankan tentang aplikasi akad salam, kurangnya pengetahuan serta pengenalan masyarakat akan seluk beluk bank syariah, serta besarnya risiko yang terkandung dalam akad salam itu sendiri (Abrista, 2011). Ketidaktahuan masyarakat tentang sistem bagi hasil yang ditawarkan oleh perbankan syariah ini diakibatkan masih kurangnya sosialisasi dan edukasi kepada masyarakat. Bank syariah harus membuat strategi edukasi dan sosialisasi yang mampu 
mengenalkan bank syariah kepada seluruh masyarakat (Arif, 2015); (4) terbatasnya jaringan perbankan syariah. Jaringan kantor perbankan syariah (termasuk BPRS) masih sangat terbatas dibandingkan perbankan konvensional. Di beberapa daerah, kantor perbankan yang malayani pendanaan maupun pembiayaan secara syariah baru dijumpai di kota-kota besar. Kondisi ini dapat berpengaruh dalam pelayanan nasabah serta ekspansi pembiayaan sektor pertanian yang sebagian besar justru masih terpusat di pedesaan. Susahnya akses ke kota guna menjangkau perbankan yang ada di kota juga menimbulkan cost yang harus dikeluarkan oleh petani. Belum lagi akan ada banyak hal yang harus diurus oleh petani seperti misalnya urusan administrasi dan sebagainya, sehingga double cost bisa saja terjadi.

Jadi dari beberapa penelitian yang telah dilakukan, penyebab dari rendahnya pembiayaan ke sektor pertanian antara lain, risiko pada pembiayaan pertanian cukup besar, kurangnya peranan bank syariah dalam pembiayaan usaha pertanian, salah satunya adalah kurangnya sosialisasi, terakhir jaringan kantor perbankan syariah (termasuk BPRS) masih sangat terbatas dibandingkan perbankan konvensional.

\section{Peluang Dan Tantangan Pembiayaan Syariah di Sektor Pertanian}

Tidak dipungkiri bahwa peranan bank syariah untuk pembiayaan usaha pertanian akan menghadapi beberapa tantangan dalam implementasinya. Tantangan tersebut dapat bersifat internal (karakteristik sektor pertanian) maupun eksternal. Sektor pertanian yang penuh resiko karena sangat bergantung pada alam akan membuat investor ekstra hati-hati untuk membiayai sektor ini. Usaha pertanian yang umumnya kecil-kecil dan tersebar juga memerlukan kepiawaian tersendiri agar biaya per unit untuk menggarap sektor ini tidak membengkak. Tantangan eksternalnya lebih banyak terkait dengan keberadaan lembaga pembiayaan syariah, sumber daya manusia (SDM), serta sosialisasinya. Sebagai lembaga yang relatif baru, pangsa pasar dan volume lembaga pembiayaan syariah belum begitu besar sehingga akan mempengaruhi kemampuan serta skala prioritas dalam pembiayaan yang dilakukan.

Demikian juga dari sisi SDM, masih harus disiapkan SDM yang mumpuni dalam bidang pembiayaan syariah sehingga tidak kesulitan pada taraf implementasinya. Selain itu kurang gencarnya sosialisasi tentang lembaga pembiayaan syariah terutama mengenai visi, misi, maupun produk yang ditawarkan juga menjadi kendala yang dapat menghambat perkembangan model pembiayaan ini. Salah satu tantangan yang cukup serius dan mempengaruhi operasional perbankan syariah dalam pembiayaan usaha adalah ketidaksesuaian 
antara aturan syariah dengan aturan yang berlaku dengan hukum positif menimbulkan kesan yang negatif dari kalangan masyarakat luas. Anggapan masyarakat bahwa label-label Islam yang melekat dalam nama bank dan produkproduknya dianggap sebagai suatu strategi untuk membangkitkan emosi keagamaan umat Islam yang dalam realitas praktisnya tidak berbeda dari bank konvensional (Muhammad, 2007: 31).

Pada sisi lain, isu sentral yang sering didengar adalah bahwa pemahaman masyarakat mengenai sistem, prinsip pelayanan dan produk perbankan yang berdasarkan syariah Islam sebagian besar masih kurang tepat. Hal demikian bukan hanya terdapat pada masyarakat awam, tetapi juga terjadi pada ulama, kiai dan tokoh masyarakat lainnya. Meskipun sistem ekonomi Islam telah jelas dan mudah dipahami, yaitu melarang menggandakan uang secara tidak produktif dan konsentrasi kekayaan pada satu pihak dan secara tidak adil. Namun secara praktis bentuk produk dan pelayanan jasa, prinsip-prinsip dasar hubungan antara bank dengan nasabah, serta cara-cara berusaha yang halal dalam bank syariah masih terasa awam dan belum dipahami secara benar. Sebagai sebuah bank yang didasarkan kepada syariah Islam, perbankan syariah dalam operasionalnya harus tunduk kepada hukum yang berlaku. Bank Islam sebagai bank komersial yang merupakan bagian integral dari sistem perbankan di Indonesia harus tunduk pada hukum atau aturan-aturan yang ditetapkan oleh pemerintah dan Bank Indonesia (Mujahidin, 2010).

Pengetahuan dan persepsi yang positif dari pihak perbankan syariah terhadap sektor pertanian akan mendorong perbankan untuk memberikan alokasi kredit yang memadai pada sektor pertanian atau sebaliknya. Di sisi lain pengetahuan dan persepsi pelaku usaha pertanian terhadap perbankan syariah akan menentukan perilaku para pelaku usaha pertanian. Ada beberapa dugaan sebab kelambanan pertumbuhan bank syariah saat ini, di antaranya adalah penerapan aturan kehati-hatian (prudential) pada bank syariah yang sama dengan yang diterapkan pada perbankan konvensional. Padahal, bank syariah pada prinsipnya harus bersedia menanggung resiko pembiayaan yang tinggi karena mengandalkan akad bagi hasil. Dipaksa oleh aturan kehati-hatian yang ketat, bank syariah pada praktiknya lebih banyak menggunakan akad jual beli yang mirip dengan kredit konvensional. Kemiripan ini menimbulkan masalah kedua di atas, di mana masyarakat yang peduli syariah menjadi tidak peduli terhadap bank syariah (Fathurrohman, 2010).

Sedangkan peluang dari pembiayaan di sektor pertanian adalah kekuatan dari sektor pertanian. Jika melihat analisa dari sudut pandang permintaan, apabila sektor pertanian kuat, maka pendapatan riil perkapita akan naik, 
permintaan petani akan produk industri manufaktur akan naik, hal ini mengindikasikan terjadi perkembangan industri manufaktur. Sedangkan ketika melihat dari sudut pandang penawaran, permintaan produk pertanian sebagai bahan baku oleh industri manufaktur. Apabila terjadi kelebihan output sektor pertanian, maka dapat digunakan sebagai investasi sektor industri manufaktur seperti industri kecil di pedesaan.

Namun pada saat ini, para ekonom sudah mulai menyadari bahwa sektor pertanian dianggap vital dari kegiatan ekonomi suatu negara. Untuk menunjang pembangunan perekonomian nasional, dapat dilakukan dengan membangun sektor pertanian. Implementasinya tidak hanya ditunjukan melalui peningkatan status dan kesejahteraan petani semata, tetapi juga berperan untuk mengembangkan potensi sumberdaya manusia baik secara ekonomi, sosial, politik, budaya, lingkungan melalui perbaikan (improvement), pertumbuhan (growth) dan perubahan (change) (Sudaryanto, 2008). Hal ini seperti yang terjadi di indonesia yang menjadi sektor pertanian menjadi sektor utama yang dapat menyangga perekonomian dalam negeri (nasution, 2016). Sebagai negara agraris, sektor pertanian dan pedesaan memiliki peran sangat strategis dalam pembangunan nasional. Namun, bukan berarti sektor pertanian dan pedesaan berjalan tanpa hambatan. Faktanya sektor tersebut sering dihadapkan pada berbagai permasalahan, terutama pada lemahnya permodalan. Sebagai unsur esensial dalam meningkatkan produksi dan taraf hidup masyarakat pedesaan, ketiadaan modal dapat membatasi ruang gerak sektor ini (ashari, 2005).

\section{Solusi Atas Rendahnya Pembiayaan Syariah Di Sektor Pertanian}

Setelah mengetahui alasan apa yang melatarbelakangi, peluang dan tantangan atas rendahnya pembiayaan syariah terhadap pembiayaan di sektor pertanian, berdasarkan permasalahan ini maka penulis mempunyai beberapa solusi yang efektif dalam menangani permalahan kasus krisis ini yaitu:

\section{A. Mengetahui Skema Pembiayaan yang sesuai dengan kebutuhan Petani}

Pengembangan lembaga pembiayaan syariah sebagai lembaga alternatif dalam pembiayaan sektor pertanian merupakan pilihan yang strategis, karena secara konseptual dianggap relevan dengan usaha sektor pertanian. Secara spesifik pembiayaan syariah bebas bunga, prinsip bagi hasil dan risiko, perhitungan bagi hasil dilakukan setelah periode transaksi berakhir. Beberapa jenis produk pembiayaan syariah yang berpeluang besar untuk diimplementasikan pada sektor pertanian diantaranya mudharabah, musyarakah, muzara'ah, murabahah, salam, istisna dan rahn. Banyaknya alternatif pembiayaan syariah ini cukup memberikan keleluasaan bagi pelaku 
bisnis pertanian untuk memilih skim pembiayaan yang disesuaikan dengan jenis kegiatan dan skala ekonomi usaha (Ashari. 2005:145).

Alternatif pola pendanaan (pembiayaan bagi hasil) yang dapat diterapkan pada usaha pertanian, antara lain:

a. Al-Musyarâkah (Partnership, Project Financing and Participation)

Penanaman dana dari shahib al-mâl (pemilik modal) untuk mencampurkan dana/modal mereka pada suatu usaha tertentu, dengan pembagian keuntungan berdasarkan nisbah yang telah disepakati sebelumnya, sedangkan kerugian ditanggung semua shahib al-mâl berdasarkan bagian dana atau modal masing-masing. Pembiayaan musyarakah bisa diaplikasikan ketika petani membutuhkan tambahan biaya untuk usahanya.

\section{b. Al-Mudharabah (Trust Financing, Trust Investment)}

Akad kerjasama antara dua pihak di mana pihak shahib al-mal menyediakan modal dan pihak mudharib menjadi pengelola. Keuntungan usaha dibagi berdasarkan nisbah sesuai dengan kesepakatan. Pembagian nisbah dapat menggunakan metode bagi untung dan rugi (profit and loss sharing) atau metode bagi pendapatan (revenue sharing). Pembiayaan mudharabah bisa diaplikasikan ketika petani membutuhkan modal awal untuk pertaniaannya.

\section{c. Al-Muzara'ah (Harverst-Yield Profit Sharing)}

Kerja sama pengolahan pertanian antara pemilik lahan dan penggarap, di mana pemilik lahan memberikan lahan pertanian kepada penggarap untuk ditanami dan dipelihara dengan imbalan bagian tertentu dari hasil panen. Biasanya diterapkan untuk pembiayaan produk pertanian (agrobased industries) atau produk-produk yang terstandarisasi. Muzara'ah bisa diaplikasikan ketika bank pertanian dan atau lembaga pembiayaan memiliki lahan pertanian menganggur atau bekerjasama dengan pemilik lahan yang tidak ingin menggarap lahannya dan petani sebagai penggarap sekaligus yang membiayai pembelian bibit dan lainnya.

\section{d. Al-Musaqah (Plantation Management Fee Based on Certain Portion of Yield)}

Bentuk sederhana dari al-Muzara'ah di mana penggarap hanya bertanggungjawab atas penyiraman dan pemeliharaan. Sebagai imbalan, si penggarap berhak atas nisbah tertentu dari hasil panen. Muzara'ah bisa diaplikasikan ketika petani tidak memiliki modal dan juga lahan.

e. Bai' al-Murâbahah (differed payment sale) 
Jual beli barang pada harga asal dengan tambahan keuntungan yang disepakati. Lembaga pembiayaan akan membelikan suatu barang yang dibutuhkan nasabah, kemudian nasabah menerima tersebut dan membayar sesuai dengan kemampuan (besarnya berdasarkan kesepakatan). Dalam sektor pertanian, dapat dimanfaatkan untuk pembelian alat dan mesin pertanian, seperti hand tractor, pompa air, dan powerthresher, rice milling unit.

\section{f. Bai' al-Salam (in front payment sale)}

Jual beli dengan ketentuan si pembeli membayar saat ini, sedangkan barang akan diterimanya di masa mendatang. Bai' al-salam berbeda dengan praktik ijon yang telah dikenal dan dipraktikkan masyarakat pedesaan hingga saat ini. Dalam sistem ijon sama sekali tidak jelas kuantitas barang yang diperjualbelikan serta sangat spekulatif. Pada bai' al-salâm disyaratkan harus jelas kuantitas, kualitas barang serta waktu pembayarannya. Bai' salam bisa diaplikasikan lembaga pembiayaan dengan bekerja sama dengan dua pihak yakni petani dan pemborong atau pembeli hasil pertanian. Dan bank disini sebagai perantara dari petani yang membutuhkan pembeli dan membutuhkan modal saat ini dengan pembeli atau yang membutuhkan hasil pertanian di masa mendatang (masa panen)

\section{g. Bai' al-Istishna (Purchase by order or manufactured)}

Fasilitas penyaluran dana untuk pengadaan barang investasi berdasarkan pesanan. Dalam transaksi, bai' al-istishna ini ada kontrak antara pembeli dan pembuat barang, di mana pembuat barang menerima pesanan dari pembeli. Kedua belah pihak bersepakat atas harga serta sistem pembayaran, apakah dilakukan dengan kontan, melalui cicilan, atau ditangguhkan pada masa mendatang. Bai' istishna bisa diaplikasikan ketika petani terkendala pembeli hasil pertaniannya namun masih ada modal. Karena dalam istishna pembayaran tidak harus di muka tidak seperti salam.

\section{h. Al-Rahn (mortage)}

Menahan salah satu harta milik si peminjam sebagai jaminan atas peminjaman yang diterimanya. Barang yang ditahan tersebut harus memiliki nilai ekonomis, dan pihak yang menahan memperoleh jaminan untuk dapat mengambil kembali seluruh atau sebagian piutangnya. Praktik gadai atau rahn sudah umum dijumpai di pedesaan.

Analisis kebutuhan petani dan akad yang bisa ditawarkan lebih jelasnya akan dirangkum dalam tabel 2 berikut: 
Tabel 2

Analisis Kebutuhan Petani

\begin{tabular}{|l|c|c|c|c|c|c|c|}
\hline \multirow{2}{*}{$\begin{array}{l}\text { Akad } \\
\text { Pembiayaan }\end{array}$} & Ladang & $\begin{array}{c}\text { Modal } \\
\text { awal }\end{array}$ & $\begin{array}{c}\text { Tambahan } \\
\text { Modal }\end{array}$ & $\begin{array}{c}\text { Bibit \& } \\
\text { Pupuk }\end{array}$ & Pengelola & $\begin{array}{c}\text { Alat } \\
\text { pertanian }\end{array}$ & $\begin{array}{c}\text { Pembeli } \\
\text { hasil } \\
\text { pertanian }\end{array}$ \\
\cline { 2 - 8 } & & $\mathrm{v}$ & & $\mathrm{v}$ & & & \\
\hline Mudharabah & & & $\mathrm{v}$ & $\mathrm{v}$ & & & \\
\hline Muzabahah'ah & $\mathrm{v}$ & & & & & & \\
\hline Musaqah & & & & & $\mathrm{v}$ & & \\
\hline $\begin{array}{l}\text { Bai' al- } \\
\text { Murabahah }\end{array}$ & & & & $\mathrm{v}$ & & $\mathrm{v}$ & \\
\hline Bai' al-Salam & & $\mathrm{v}$ & & & & & $\mathrm{v}$ \\
\hline Bai' al-istishna & & & & & & & $\mathrm{v}$ \\
\hline Rahn & & $\mathrm{v}$ & $\mathrm{v}$ & $\mathrm{v}$ & & $\mathrm{v}$ & \\
\hline
\end{tabular}

Sumber: data diolah dari berbagai sumber

Pola-pola pembayaran yang fleksibel dan disesuaikan dengan pola cash flow nasabah yang dirancang dalam skim ini, akan membantu masyarakat yang bergerak di sektor pertanian (lihat tabel 3).

Tabel 3

Akad Pembiayaan di Perbankan Syariah

\begin{tabular}{|c|c|c|c|c|c|c|c|c|c|c|c|c|c|}
\hline & $\mathbf{2 0 0 4}$ & $\mathbf{2 0 0 5}$ & $\mathbf{2 0 0 6}$ & $\mathbf{2 0 0 7}$ & $\mathbf{2 0 0 8}$ & $\mathbf{2 0 0 9}$ & $\mathbf{2 0 1 0}$ & $\mathbf{2 0 1 1}$ & $\mathbf{2 0 1 2}$ & $\mathbf{2 0 1 3}$ & $\mathbf{2 0 1 4}$ & $\mathbf{2 0 1 5}$ & $\mathbf{2 0 1 6}$ \\
\hline Mudharabah & 11,1 & 12,5 & 11,4 & 15,8 & 19,4 & 22,2 & 12,7 & 10,0 & 8,2 & 7,2 & 7,4 & 11,6 & 10,9 \\
\hline Musyarakah & 18,0 & 20,5 & 19,9 & 20,0 & 16,3 & 14,1 & 21,4 & 18,5 & 18,8 & 21,7 & 24,8 & 22,6 & 34,5 \\
\hline Murabahah & 66,5 & 62,3 & 61,8 & 59,2 & 58,9 & 56,1 & 55,0 & 54,9 & 59,7 & 60,0 & 58,9 & 48,2 & 41,8 \\
\hline Salam & 0,0 & 0,0 & 0,0 & 0,0 & 0,0 & 0,0 & 0,0 & 0,0 & 0,0 & 0,0 & 0,0 & 0,0 & 0,0 \\
\hline Istishna & 2,7 & 1,9 & 1,7 & 1,3 & 1,0 & 0,9 & 0,5 & 0,3 & 0,3 & 0,3 & 0,3 & 1,1 & 1,2 \\
\hline Ijarah & 0,0 & 0,0 & 0,0 & 0,0 & 2,5 & 2,8 & 3,4 & 3,7 & 5,0 & 5,7 & 5,8 & 15,36 & 10,3 \\
\hline Qardh & 0,0 & 0,0 & 0,0 & 0,0 & 2,0 & 3,9 & 6,9 & 12,6 & 8,2 & 4,9 & 3,0 & 1,1 & 1,2 \\
\hline Lainnya & 1,8 & 2,9 & 5,3 & 3,8 & 0,0 & 0,0 & 0,0 & 0,0 & 0,0 & 0,0 & 0,0 & 0,0 & 0,0 \\
\hline
\end{tabular}

Sumber : Otoritas Jasa Keuangan, $2004-2016$, diolah 
Peranan bank syariah dapat ditingkatkan dengan menggunakan kekuatan untuk mengatasi kelemahan dan menggunakan peluang untuk meminilisasi tantangan, khususnya untuk pembiayaan usaha pertanian di Indonesia. Berdasarkan pertimbangan tersebut, maka upaya meningkatkan peranan bank syariah untuk pembiayaan usaha pertanian menggunakan strategi sebagai berikut: Pertama, mengembangkan kantor bank syariah pada daerah pertanian; Kedua, memberikan pembiayaan syariah seperti alMuzâra'ah (Harverst-Yield Profit Sharing), Bai' al-salâm (in front payment sale); Bai' almurâbahah (differed payment sale), dan al-Rahn; Ketiga, melakukan pemasaran produk pembiayaan bank syariah kepada usaha pertanian terutama yang memiliki prospek pasar yang cukup besar; Keempat, melakukan pemasaran produk pembiayaan bank syariah kepada usaha pertanian yang dilakukan kelompok tani atau gabungan kelompok tani andalan; Kelima, memberikan pembiayaan bank syariah yang sesuai dengan usaha pertanian secara penuh, agar potensi kegagalan panen dapat diminimalisir.

\section{B. Optimalisasi peran LKMS}

Masih banyaknya masyarakat yang belum bersentuhan dengan lembaga keuangan, khususnya di lembaga keuangan mikro syariah (LKMS) merupakan salah satu permasalahan pengembangan lembaga keuangan tersebut. Untuk mengatasi permasalahan ini diperlukan solusi agar masyarakat memiliki akses ke dalam lembaga keuangan melalui inovasi produk, proses dan saluran distribusi yang tepat. Sehingga manfaat dari adanya LKMS ini bisa dirasakan oleh seluruh lapisan masyarakat, terutama untuk masyarakat menengah bawah. Keterlibatan masyarakat dalam suatu lembaga keuangan diperlukan karena institusi keuangan memainkan peran penting melalui fungsi intermediasinya untuk mendorong pertumbuhan ekonomi, pemerataan pendapatan, pengentasan kemiskinan serta pencapaian stabilitas sistem keuangan. Berdasarkan permasalahan di atas maka diperlukan kajian komprehensif terkait Pengembangan LKMS terutama BMT agar produk dan jasa keuangan syariah bisa dinikmati oleh masyarakat secara luas termasuk para petani. Hal ini dikarenakan tugas BMT lebih mengarah pada usaha-usaha pengumpulan dan penyaluran dana yang bersifat non-profit. BMT juga menerima titipan dana zakat, infak dan shadaqah, serta mengoptimalkan distribusinya sesuai dengan pengelolaannya berdasarkan prinsip-prinsip Syariah. BMT juga berfungsi sebagai pendukung adanya kemungkinan terjadinya risiko yang terjadi dalam kegiatan ekonomi para pelaku usaha yang menjadi anggota (Masrifah, 2017).

Para petani sendiri umumnya adalah unbankable people, dengan memaksimalkan fungsi BMT, diharapkan dapat meningkatkan kapasitas petani. Salah satu cara pendekatan yang harus dilakukan antara BMT dan petani adalah dengan cara memberikan sosialisasi dan edukasi kepada petani. Melalui program sosialisasi, edukasi dan komunikasi baik kepada seluruh petani yang terdapat dalam jangkauan pasar BMT tersebut, diharapkan nantinya para petani tersebut memiliki kesadaran dan mau menitipkan dananya ataupun melakukan pembiayaan melalui BMT. 


\section{Membentuk Bank Pertanian Syariah}

Dengan mendirikan bank pertanian maka akad salam dapat diterapkan guna menjadi salah satu model pembiayaan untuk pertanian. Menurut kalangan pakar, mereka berpendapat bahwa dalam mendirikan bank pertanian perlu ada masa transisi. Artinya, bank pertanian tidak langsung berdiri sebagai wujud bank yang dalam aspek hukumnya pun harus tunduk dan memenuhi syarat-syarat hukum perbankan. Akan tetapi, bank pertanian dapat dibentuk melalui lembaga-lembaga BUMD. Strategi ini pula yang menjadi prioritas berdasarkan pada data gabungan antara pakar dan praktisi (Abrista, 2011) untuk alternatif menghindari pinjaman permodalan berbasis bunga. Skema pembiayaan dalam bank pertanian bisa menggunakan yang teah dijelaskan diatas tentang alternatif pembiayaan dengan identifikasi kebutuhan nasabah.

\section{Reward and Punishment}

Prioritas selanjutnya ialah dengan insentif skim, baik berupa reward maupun berbentuk punishment. Insentif dapat diberikan tergantung kebijakan dari lembaga bersangkutan. Pemberian bonus tidak dilarang dengan catatan tidak disyaratkan sebelumnya dan secara jumlah tidak ditetapkan dalam nominal atau persentasi. Insentif diberikan kepada nasabah yang melakukan angsuran tepat waktu (misalnya: keterlambatan maksimal tiga hari kerja) selama jangka waktu pembiayaan akan diberikan insentif. Sedangkan punishment (sanksi) diberikan kepada nasabah jika terjadi keterlambatan pembayaran angsuran sesuai dengan tanggal yang telah ditentukan. Dampak psikologis dengan adanya pemberlakuan reward and punishment akan berpengaruh terhadap kepatuhan dan ketaatan serta kedisiplinan pembayaran angsuran.

\section{SIMPULAN}

Penyebab rendahnya pembiayaan syariah di sektor pertanian antara lain, risiko pada pembiayaan pertanian cukup besar, kurangnya peranan bank syariah dalam pembiayaan usaha pertanian, salah satunya adalah kurangnya sosialisasi, terakhir jaringan kantor perbankan syariah (termasuk BPRS) masih sangat terbatas dibandingkan perbankan konvensional. Peluang pembiayaan syariah sektor pertanian dapat terlihat dari besarnya permintaan produk pertanian sebagai makanan pokok di Indonesia sehingga bisa dimanfaatkan untuk meningkatkan dan mengoptimalkan produksi pertanian. Namun tantangan pembiayaan syariah di sektor pertanian adalah kualitas SDM pengelola pembiayaan dan sektor petani yang masih relatif banyak resiko.

Solusi atas rendahnya pembiayaan syariah di sektor pertanian antara lain mengetahui Skema Pembiayaan yang sesuai dengan kebutuhan Petani, optimalisasi peran LKMS, membentuk Bank Pertanian Syariah, serta diberlakukannya reward and punishment.

\section{DAFTAR PUSTAKA}


Pembiayaan Syariah Di Sektor Pertanian ...

$\cdots$

Affandi, Anas. (2014). “Makna Pembiayaan Salam Perspektif Perbankan Syariah Dan Petani Di Probolinggo". Jurnal IImiah Mahasiswa FEB, 2 (2).

Antonio, M. Syafi'i. (2001). Bank Syariah dari Teori ke Praktek. Jakarta: Gema Insani Press.

Arif, Nur Rianto. (2015). Pengantar Ekonomi Syariah Teori dan Praktik, Bandung: Pustaka Setia.

Arifin, Bustanul. (2004). Analisis Ekonomi Pertanian Indonesia.Jakarta: Penerbit Buku Kompas.

Assad. (2011). “Peningkatan Peranan Perbankan Syariah Untuk Pembiayaan Usaha Pertanian". Miqot 35 (1):

Ashari, Saptana. (2005). "Prospek Pembiayaan Syariah Untuk Sektor Pertanian", Forum Penelitian Agro Ekonomi, 23 (2): 145-146.

Ashari. (2009). "Roles of National Banking in Agricultural Finance in Indonesia." Forum Penelitian Agro Ekonomi 27 (1): 13-27.

Devi, Abrista. (2011). "Analisis faktor-faktor yang mempengaruhi tidak diterapkannya pembiayaan akad Bay' As-salam di Bank Syariah Indonesia." Riset Perbankan Syariah,4..

Ismail. (2010). Perbankan Syariah. Jakarta: Kencana.

Mançka, Anila. (2012). "Lending Problems of Agriculture and Agro-Industry in Albania". Ontario International Development Agency. International Journal Of Sustainable Development, 03 (04).

Masrifah, Atika R. (2010). "Baitul Mal Wat Tamwil (BMT) sebagai Alternatif Strategis Memajukan Usaha Mikro Kecil Sektor Pertanian". Islamic Economic Journal, 3 (1): $115-40$

Roziq, A et.al. (2014). "Model Pembiayaan Salam pada Petani Singkong Dan Usaha Kecil Berbahan Singkong di Kabupaten Jember". Jurnal Akuntansi Universitas Jember, 12 (2).

Sudaryanto, Iqbal. (2008). “Kebijakan Paradigma Pembangunan dan Kebijaksanaan Pengembangan Agroindustri", Pusat Penelitian dan Pengembangan Sosial Ekonomi Pertanian.

Wirdyaningsih. (2005). Bank dan Asuransi Islam di Indonesia. Jakarta: Prenada Media

Wulandari, S dan Suroso, Al. 2004. "Lembaga Keuangan Syariah Alternatif Strategis Memajukan Sektor Agribisnis”. Agrimedia, 9 (1): 40-53 